Vol. 4: 495-501.

\title{
Determination of barley nitrogen status with chlorophyll meter for high $\beta$-amylase in grains
}

\author{
Jari Peltonen and Ari Virtanen \\ Plant Production Inspection Centre, Seed Testing Department, P.O. Box 111, FIN-32201 Loimaa, Finland
}

Jaakko Helenius, Juha Salopelto and Kari Kiltilä

Cultor Ltd., Helsinki

Esko Eloranta

Neson Ltd., Jokioinen

\begin{abstract}
The production of $\beta$-amylase is of great importance in two-rowed spring barley cv. Kymppi (Hordeum vulgare $\mathrm{L}$.) in the Finland, where long-day conditions favour high enzyme activities. Nitrogen (N) fertilization of a crop is the main means of manipulating barley $\beta$-amylase activity for industrial purposes. In this study, leaf chlorophyll content determined with a portable chlorophyll meter (Minolta SPAD-502) in the field, was used to predict $\mathrm{N}$ availability of cv. Kymppi for $\beta$-amylase production. Critical chlorophyll meter readings (SPAD values) were calculated from data deriving from experiments with various $\mathrm{N}$ fertilizer levels using the Cate-Nelson procedure. According to the results of this study it can be stated that the critical SPAD values at pollination (i.e. pollen grains on well-developed stigmatic hairs, GS 52-58) are 37 SPAD units for grain yield and 41 SPAD units for $\beta$-amylase activity. The optimum grain yield occurred at 41 SPAD units and optimum $\beta$-amylase activity was reached at 45 SPAD units. Determination of leaf chlorophyll content using the chlorophyll meter led to more appropriate fertilizer application recommendations and subsequently increased $\beta$-amylase activity in grains. Grain protein concentration could be an effective diagnostic tool for post-harvest evaluation of grain $\beta$-amylase activity in cv. Kymppi.
\end{abstract}

Key words: $\beta$-amylase activity, grain protein concentration, grain yield, chlorophyll content, plant tissue $\mathrm{N}$ status

\section{Introduction}

$\beta$-amylase is an important barley (Hordeum vulgare L.) protein, determining the technical quality of starch used for various industrial processes in Finland (Helenius 1992). Cultivars with high $\beta$-amylase activity are often reported to be high in grain protein concentration (Harris and Banasik 1952). However, Helenius (1992) indicated that although increases in grain protein concentration led to increased $\beta$-amylase activity in grain, $\beta$-amylase activity differed among barley varieties: two-rowed Kymppi had - and

(C) Agricultural Science in Finland

Manuscript received December 1995 
Peltonen, J. et al.: Determination of barley nitrogen status with chlorophyll meter for high $\beta$-amylase in grains

still has - the highest $\beta$-amylase activity among barley varieties grown in Finland.

Nitrogen (N) fertilization of a crop is the main means of manipulating barley $\beta$-amylase activity for industrial purposes (Hayter and Riggs 1973). Previously, Peltonen et al. (1995) showed that leaf chlorophyll content, determined in the field with a portable Minolta SPAD-502 chlorophyll meter (developed by the Soil-Plant Analyses Development Section of Minolta Camera Company, Ramsey, NJ) ${ }^{1}$, accurately indicated plant $\mathrm{N}$ status of small-grain cereals, allowing $\mathrm{N}$ fertilizer requirements to be determined accurately. Applying $\mathrm{N}$ fertilizer on this basis improved production economics and improved the physical input-output ratio during grain yield formation (Peltonen et al. 1995).

The objectives of this research were to quantify relationships between yield, grain protein concentration, $\beta$-amylase activity and SPAD values measured with a Minolta chlorophyll meter. The specific goals were to evaluate the potential for calibrationing the meter to optimize cv. Kymppi $\mathrm{N}$ status and predict the need for supplemental $\mathrm{N}$ fertilization for increasing $\beta$-amylase activity. Finally, the $\beta$-amylase stability of an optimized production system was evaluated using SPAD values.

\section{Material and methods}

\section{Field trials}

Field trials (Series 1) included five separate experiments at Experimental Farms of the University of Helsinki (Viikki and Suitia in 1993 and 1994) and at the Experimental Farm of Kemira Ltd. (Kotkaniemi in 1993) with two-rowed spring barley cv. Kymppi. A row spacing of 12.5 $\mathrm{cm}$ and 500 viable seeds $\mathrm{m}^{-2}$ were used. Nitrogen $\left(\mathrm{NH}_{4} \mathrm{NO}_{3}-\mathrm{N}\right)$ was applied to three $10 \mathrm{~m}^{2}$ replicated blocks at $0,50,100,150$ and $200 \mathrm{~kg} \mathrm{~N}$

\footnotetext{
1 Trade and company names are included for the benefit of the readers and do not imply any endorsement or preferential treatment of the product by the authors.
}

ha $^{-1}$ at Viikki and Suitia, and 0, 40, 80, 120 and $160 \mathrm{~kg} \mathrm{~N} \mathrm{ha}^{-1}$ at Kotkaniemi. Nitrogen fertilizer was applied $7 \mathrm{~cm}$ deep at sowing. P, K, Ca, S, $\mathrm{Mg}, \mathrm{Zn}$ and $\mathrm{Mn}$ were also applied at sowing according to Finnish soil test recommendations: phosphorus availability in particular may influence calibration of the SPAD 502 meter (Follet et al. 1992). This program yielded a series of samples with increasing grain yield, grain protein concentration and $\beta$-amylase activity. Standard crop protection procedures (herbicide and fungicide) were implemented.

The plots were harvested when grains reached the caryopsis hard stage (GS 92, Zadoks et al. 1974). Yield was determined at $15 \%$ grain moisture content. The grain samples from each of the three replicates were combined and mixed thoroughly. Grain protein concentration was determined from whole grain meal using the standard method 46-11 of the AACC (1983). $\beta$-amylase activity was determined according to a method described by Helenius (1992).

\section{Chlorophyll measurements}

Chlorophyll meter readings (SPAD values) were taken at the stage of maximum number of florets per ear primordium (FM), coinciding with Zadoks' GS 37-41, and at pollination (PO), i.e. pollen grains on well-developed stigmatic hairs (GS 52-58). The developmental stage of the inflorescence was determined according to the scale of Waddington et al. (1983), and was considered to be reached when at least $60 \%$ of plants were at that stage. It has been indicated (Peltonen 1992) that these developmental stages are important for timing of supplemental $\mathrm{N}$ applications. Thirty randomly selected plants per plot were used for determining the chlorophyll content. Determination of the SPAD value was made from mid-length on the uppermost fully expanded leaf.

\section{Statistical analysis of critical readings}

The critical levels of leaf chlorophyll were established using Cate-Nelson analysis (Cate and Nelson 1971, Nelson and Andersen 1977). The 
Vol. 4: 495-501.

Cate-Nelson II model partitioned the data for critical SPAD values into two group in terms of grain yields; $\mathrm{N}$ fertilizer responsive and non-responsive. The Cate-Nelson III model partitioned the data into three groups; $\mathrm{N}$ fertilizer responsive, transitional and non-responsive. Grain yield was expressed as a percentage yield $\mathrm{Y}_{i} / \mathrm{Y}_{\max } \times$ 100 where $Y_{i}$ is the grain yield when $\mathrm{N}_{i} \mathrm{~kg} \mathrm{ha}^{-1}$ was applied, and $\mathrm{Y}_{\max }$ is the maximum grain yield obtained in an experiment. The increase in grain protein concentration $(\mathrm{P})$ and in $\beta$-amylase activity $(\beta)$ were calculated as $\triangle P_{i}=P_{i}-P_{0}$ and $\Delta \beta=\beta_{i}$ $\beta_{0}$, where $P_{0}$ and $\beta_{0}$ is control of grain protein and $\beta$-amylase activity, respectively. Actual grain yield, grain protein concentration and $\beta$-amylase activity, as functions of the SPAD values, were consistently the best in terms of the coefficient of determination $\left(\mathrm{R}^{2}\right)$.

\section{On-farm trials}

The accuracy of the critical and optimal SPAD values for optimizing $\mathrm{N}$ fertilizer application for maximum $\beta$-amylase production was studied using independent barley (cv. Kymppi) data from
24 on-farm trials (Series 2) in southern Finland in 1995. Nitrogen fertilizer application at sowing ranged from 41 to $115 \mathrm{~kg} \mathrm{~N} \mathrm{ha}^{-1}$. The SPAD values were measured at the pollination (PO) developmental stages as in Series 1. The barley fields were grouped into categories of near optimum plant $\mathrm{N}$ status and excess $\mathrm{N}$, according to the critical SPAD values for Series 1 .

\section{Results and discussion}

The temperatures during crop growth in 1993 and 1994 were close to the mean for the period 19611990 , but approximately $60-80 \mathrm{~mm}$ more rain fell prior to heading in 1993 and 1994 than during 1961-1990. This weather promoted very high grain yields and a very good response to $\mathrm{N}$ fertilizer in Finland. The grain yield, grain protein concentration and $\beta$-amylase activity for all experiments are presented in Table 1. The maximum grain yields obtained in Series 1 were 7292 $\mathrm{kg} \mathrm{ha}^{-1}$ in 1993 and $6252 \mathrm{~kg} \mathrm{ha}^{-1}$ in 1994 . These maximum yield levels were clearly higher than

Table 1. Grain yield, grain protein concentration and $\beta$-amylase activity as functions of $\mathrm{N}$ application rate for spring barley cv. Kymppi grown 1993 and 1994.

\begin{tabular}{|c|c|c|c|c|c|c|}
\hline Location and year & Trait & $\mathrm{N}^{\mathrm{a}}$ & N2 & N3 & N4 & N5 \\
\hline \multirow[t]{3}{*}{ Viikki 1993} & Grain yield kg ha- ${ }^{1}$ & 3933 & 6140 & 6786 & 7292 & 7220 \\
\hline & Grain protein $\%$ & 8.8 & 9.4 & 10.2 & 11.5 & 12.4 \\
\hline & $\beta$-amylase activity W.K. & 80 & 87 & 111 & 149 & 235 \\
\hline \multirow[t]{3}{*}{ Suitia 1993} & Grain yield $\mathrm{kg} \mathrm{ha}^{-1}$ & 4023 & 5680 & 6028 & 7058 & 6570 \\
\hline & Grain protein \% & 9.4 & 9.6 & 11.9 & 12.1 & 13.3 \\
\hline & $\beta$-amylase activity W.K. & 95 & 115 & 165 & 212 & 267 \\
\hline \multirow[t]{3}{*}{ Kotkaniemi 1993} & Grain yield $\mathrm{kg} \mathrm{ha}^{-1}$ & 2040 & 4290 & 4930 & 5310 & 5600 \\
\hline & Grain protein $\%$ & 6.9 & 8.3 & 11.0 & 12.9 & 14.1 \\
\hline & $\beta$-amylase activity W.K. & 77 & 87 & 129 & 200 & 253 \\
\hline \multirow[t]{3}{*}{ Viikki 1994} & Grain yield $\mathrm{kg} \mathrm{ha}^{-1}$ & 4355 & 5449 & 5951 & 5799 & 5598 \\
\hline & Grain protein $\%$ & 9.8 & 12.1 & 12.8 & 13.5 & 15.8 \\
\hline & $\beta$-amylase activity W.K. & 131 & 176 & 229 & 256 & 332 \\
\hline \multirow[t]{3}{*}{ Suitia 1994} & Grain yield $\mathrm{kg} \mathrm{ha}^{-1}$ & 3530 & 5660 & 6092 & 6164 & 6252 \\
\hline & Grain protein $\%$ & 9.4 & 11.1 & 13.3 & 14.3 & 15.4 \\
\hline & $\beta$-amylase activity W.K. & 102 & 134 & 212 & 231 & 253 \\
\hline
\end{tabular}

a $\mathrm{N} 1=0, \mathrm{~N} 2=50, \mathrm{~N} 3=100, \mathrm{~N} 4=150$ and N5 $=200 \mathrm{~kg} \mathrm{~N}^{2}-^{-1}$ at Viikki and Suitia $\mathrm{N} 1=0, \mathrm{~N} 2=40, \mathrm{~N} 3=80, \mathrm{~N} 4=120$ and N5 $=160 \mathrm{~kg} \mathrm{~N}^{\mathrm{N}} \mathrm{-}^{-1}$ at Kotkaniemi 


\section{AGRICULTURAL SCIENCE IN FINLAND}

Peltonen, J. et al.: Determination of barley nitrogen status with chlorophyll meter for high $\beta$-amylase in grains

annual mean yields in Finland, which, according to Mukula and Rantanen (1989), are about $3000 \mathrm{~kg} \mathrm{ha}^{-1}$ for spring barley. The higher the $\mathrm{N}$ fertilizer rate the higher was $\beta$-amylase activity and grain protein concentration. The maximum $\beta$-amylase activity and grain protein concentration values were obtained at Suitia in 1993 and at Viikki in 1994.

\section{Critical chlorophyll meter readings}

Leaf chlorophyll content, determined with the chlorophyll meter, correlated strongly with grain yield at the stage of maximum number of florets per ear primordium (FM), but poorly with grain protein concentration and $\beta$-amylase activity (not shown in Table 2). In turn, leaf chlorophyll content at the stage of pollen grains on well-developed stigmatic hairs (PO) correlated more strongly with grain yield, grain protein concentration and $\beta$-amylase activity. Therefore, the Cate-Nelson analyses were performed only on data taken at this developmental stage. CateNelson III model produced significantly higher $\mathrm{R}^{2}$ values than Cate-Nelson II models. Both models for critical and optimum SPAD units are shown in Table 2.

Table 2. Cate-Nelson equations describing grain yield, grain protein concentration and $\beta$-amylase activity in relation to leaf chlorophyll (SPAD) levels, and suggested critical chlorophyll meter readings for spring barley cv. Kymppi at $\mathrm{PO}^{a}$.

\begin{tabular}{l}
\hline Equation \\
\hline Grain yield $=3576+1868 \times \mathrm{X}_{1}+733 \times \mathrm{X}_{2}$ \\
where $\mathrm{x}_{1}=0$ if $<37$ SPAD and 1 if $>37$ SPAD \\
where $\mathrm{x}_{2}=0$ if $<41$ SPAD and 1 if $>41$ SPAD \\
Grain protein concentration $=9.5+4.7 \times \mathrm{X}_{1}-1.8 \times \mathrm{X}_{2} \quad 0.74^{* * * *}$ \\
where $\mathrm{x}_{1}=0$ if $<41$ SPAD and 1 if $>41$ SPAD \\
where $\mathrm{x}_{2}=0$ if $<45$ SPAD and 1 if $>45$ SPAD \\
$\beta$-amylase activity $=109+143 \times \mathrm{X}_{1}-51 \times \mathrm{X}_{2} \quad 0.72^{* * *}$ \\
where $\mathrm{x}_{1}=0$ if $<41$ SPAD and 1 if $>41$ SPAD \\
where $\mathrm{x}_{2}=0$ if $<45$ SPAD and 1 if $>45$ SPAD \\
\hline
\end{tabular}

*** Significant at the 0.001 probability level.

a $\mathrm{PO}=$ stage of pollen grains on well-developed stigmatic hairs, coinciding with Zadoks' GS 52-58.
These results show that the application of sufficient $\mathrm{N}$ to spring barley cv. Kymppi, according to the recommendations based on leaf chlorophyll content (SPAD units) at PO, ranking "low" in N would result in an average response of $3576 \mathrm{~kg} \mathrm{ha}^{-1}$ in grain yield as compared with an average response of $1868 \mathrm{~kg}$ more grain $\mathrm{ha}^{-1}$ for the "medium N" class. In class "high", the grain yield would change only by $733 \mathrm{~kg} \mathrm{ha}^{-1}$ compared with class "medium". For grain protein concentration and $\beta$-amylase activity the critical SPAD values were 41 units and the optimum SPAD values 45 units. This indicates that the use of $\mathrm{N}$ fertilization in excess of the amount needed for an optimum grain yield (SPAD values exceeding 41 units) will generally result in increased grain protein concentration and $\beta$-amylase activity, but not necessarily in grain yield. The likely reason for this is that the photosynthetic rate, which is important in determining yield potential, will not increase to the same extent as the nitrate reductase activity of the plant (Lawlor et al. 1987, Joy and Peltonen 1993). In this study, chlorophyll content within the zone of adequacy resulted in $14.2 \%$ of grain protein and 252 W.K. of $\beta$-amylase activity. However, if the SPAD values ranked "high", indicating over optimum N status, there would be a 51 W.K. decrease in the $\beta$-amylase activity of grains (Table 2).

\section{Effect of optimized $\mathrm{N}$ management on $\beta$-amylase production stability using SPAD values}

Yields were high in 1995 in on-farm trials (Series 2 ) and generally there were strong $\mathrm{N}$ responses. There were also large differences between applied $\mathrm{N}$ fertilizer and $\beta$-amylase activities in on-farm trials when the 24 fields were grouped into zones of $\mathrm{N}$ deficiency, optimum $\mathrm{N}$ status and excess $\mathrm{N}$ in plants using SPAD values (Table 3). Surprisingly, the better N fertilized fields suffered $\mathrm{N}$ deficiency for $\beta$-amylase production. Data indicated that 11 of the 24 growers succeeded in optimizing the $\mathrm{N}$ management 
Vol. 4: 495-501.

without information on plant $\mathrm{N}$ status. Plant $\mathrm{N}$ status was supraoptimal only in two of 24 spring barley fields surveyed, although the lower dose of $\mathrm{N}$ fertilizer was fell within the optimum SPAD zone. The plant $\mathrm{N}$ deficiency among 11 fields examined resulted in 19 W.K. lower $\beta$-amylase activity than for optimal N status. Based on these data, growers are advised to pursue more vigorously the $\mathrm{N}$ fertilization program in their barley fields to promote $\beta$-amylase production.

The data above indicate that the capacity of SPAD values for predicting crop $\mathrm{N}$ status and $\beta$ amylase activity at given developmental stages is especially promising. Calculations using Series 1 for the category of adequacy, where the SPAD readings increased from 41 to 45 , increased $\beta$-amylase activity by 143 W.K. and required about $130 \mathrm{~kg}$ more $\mathrm{N} \mathrm{ha}^{-1}$, when compared with the category where the grain yield reached a plateau (data not shown). Thus, to increase $\beta$-amylase activity by 10 W.K. with $\mathrm{N}$ fertilization, $11 \mathrm{~kg}$ more $\mathrm{N} \mathrm{ha}^{-1}$ was required, which corresponded to $40 \mathrm{FIM} \mathrm{ha}^{-1}$ input [calculated using a $\mathrm{N}$ (foliar urea) cost of $1.68 \mathrm{FIM} \mathrm{kg}^{-1}$ ]. The model developed provides useful information for calculating the price per unit $\beta$-amylase activity as a routine part of marketing cv. Kymppi. In
Table 3. Comparison of the effect of the intensiveness of $\mathrm{N}$ fertilization, based on chlorophyll meter readings, on $\beta$-amylase production in spring barley cv. Kymppi in 24 on-farm trials.

\begin{tabular}{lcc}
\hline $\begin{array}{l}\text { Intensiveness of } \mathrm{N} \\
\text { fertilization according } \\
\text { to SPAD readings }\end{array}$ & $\begin{array}{c}\text { Mean applied } \\
\mathrm{N} \text { fertilizer } \\
\text { rate }^{\mathrm{a}}\end{array}$ & $\begin{array}{c}\beta \text {-amylase } \\
\text { activity }\end{array}$ \\
\hline & $\mathrm{kg} \mathrm{ha}^{-1}$ & W.K. \\
< Critical SPAD & $104(11)$ & 128 \\
Adequate SPAD & $94(11)$ & 147 \\
$>$ Optimum SPAD & $70(2)$ & 160 \\
\hline
\end{tabular}

${ }^{a}$ Number of growers in parentheses

addition, based on the knowledge of this physical input-output ratio, growers could express the calculations in economical terms, knowing the current fertilizer cost and price of barley grain and the unit increase in $\beta$-amylase activity.

\section{Post-harvest evaluation of $\beta$-amylase activity with grain protein concentration}

Grain protein concentration of barley cv. Kymppi correlated strongly with $\beta$-amylase activity (Fig. 1), thus confirming findings of Harris and

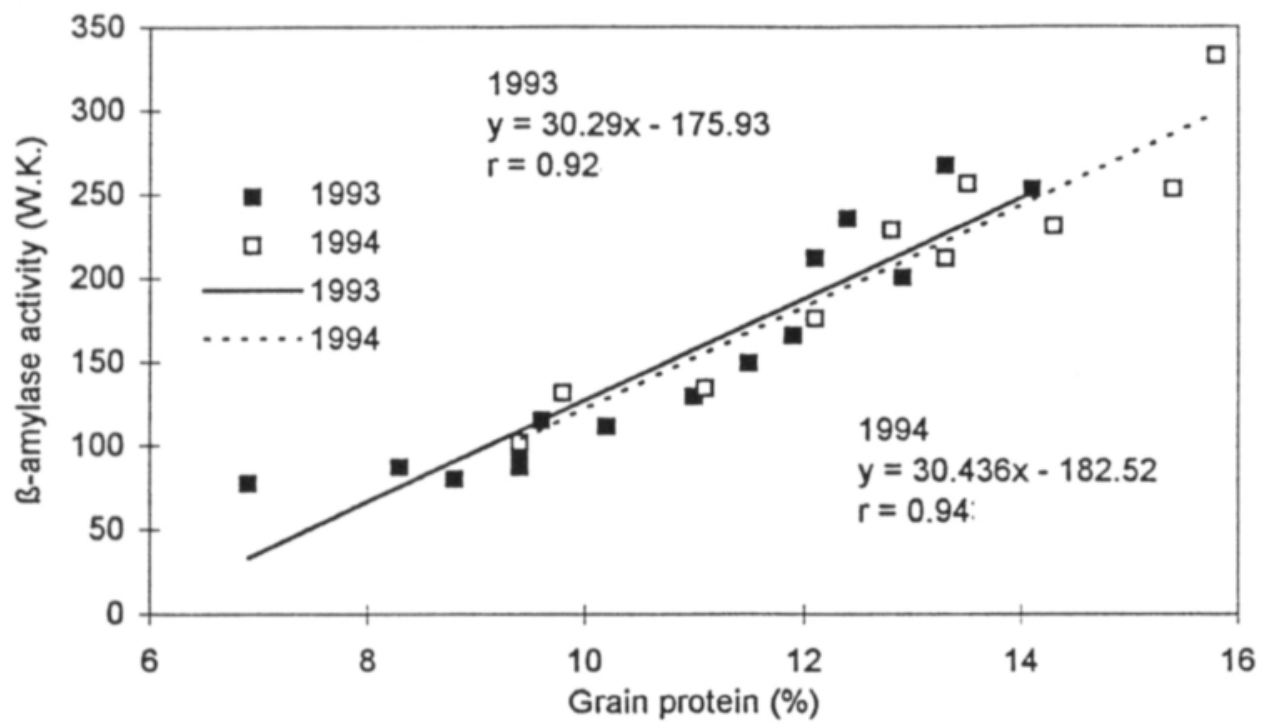

Figure 1. Relationship between grain protein concentration (\%) and $\beta$-amylase activity (W.K.) in 1993 and 1994. 
Peltonen, J. et al.: Determination of barley nitrogen status with chlorophyll meter for high $\beta$-amylase in grains

Table 4. Suggested critical tissue chlorophyll (SPAD) levels for spring barley cv. Kymppi at POa in Finland.

\begin{tabular}{lccc}
\hline Traits & <Critical & Adequate $^{c}$ & $>$ Optimum $^{d}$ \\
\hline Grain yield kg ha & & \\
Grain protein concentration $\%$ & 37 & $37-41$ & 46 \\
$\beta$-amylase activity W.K. & 41 & $41-45$ & 48 \\
\hline
\end{tabular}

a $\mathrm{PO}=$ stage of pollen grains on well-developed stigmatic hairs, coinciding with Zadoks' GS 52-58.

${ }^{b}$ Critical levels were calculated from Cate-Nelson II models.

${ }^{c}$ Lower and upper limits for adequate SPAD values were developed from Cate-Nelson III models. Adequacy level can be given if Cate-Nelson III models are an improvement in terms of $\mathrm{R}^{2}$ in respect to CateNelson II models.

${ }^{d}$ Mean values for class of > optimum SPAD, where there were no more increases in grain yield, grain protein concentration and $\beta$-amylase activity.

Banasik (1952). There were no significant differences for levels and slopes of linear regression functions between years (data not shown), indicating that grain protein concentration can be used for post-harvest evaluation of $\beta$-amylase activity in Kymppi within and between seasons. A grain protein concentration of $11 \%$ indicated $\beta$-amylase activity of $152-157$ W.K. and at least $14 \%$ of grain protein should be reached for $\beta$-amylase activity to exceed $250 \mathrm{~W}$.K.

\section{Conclusions}

In conclusion, the results from this study indicated that making accurate $\mathrm{N}$ fertilizer recommendations based on chlorophyll meter (Minolta SPAD-502) readings was economically advantageous. Determination of leaf chlorophyll content (SPAD values) using the chlorophyll meter allowed more appropriate fertilizer application recommendations to be made and promote a subsequent increase in $\beta$-amylase activity of a crop. Applying $\mathrm{N}$ fertilizer "as needed" resulted in a better physical input-output ratio than with lower or higher $\mathrm{N}$ inputs. Based on the knowledge of the physical input-output ratio, one could express the calculations in economical terms, knowing the current fertilizer cost and price of barley grain and unit increase in $\beta$-amylase activity.

Chlorophyll content can be assessed rapidly. The meter's cost may be prohibitive for many farmers, but not for large growers, consultants and groups including crop management associations. SPAD values for delimiting responsive and non-responsive ranges at pollination (i.e. pollen grains on well-developed stigmatic hairs, GS 52-58) are summarized in Table 4. The capacity of SPAD values to predict barley $\mathrm{N}$ status at this stage is especially promising, because supplemental $\mathrm{N}$, applied as foliar sprayed with urea-ammonium-nitrate (Turley and Ching 1986) could easily be applied at this time of development to increase grain protein concentration and hordein synthesis. The suggested critical SPAD values are suitable under growing conditions where good response of grain yield to $\mathrm{N}$ fertilization occurs. The SPAD values for optimum grain yield are 4 SPAD units lower than the SPAD values for optimum $\beta$-amylase activity for Kymppi. Grain protein concentration could be an effective diagnostic tool for post-harvest evaluation of grain $\beta$-amylase activity in Kymppi. 
Vol. 4: 495-501.

\title{
References
}

AACC 1983. Approved methods of the AACC, Vol. I,II. 8th Ed. Method 46-11. American Association of Cereal Chemists, Inc., St. Paul, Minnesota, U.S.A.

Cate, R.B. \& Nelson, L.A. 1971. A simple statistical procedure for partitioning soil test correlation data into two classes. Soil Science Society of America Proceedings 35: 658-660.

Follet, R.H., Follet, R.F. \& Halvorson, A.D. 1992. Use of a chlorophyll meter to evaluate the nitrogen status of dryland winter wheat. Communication of Soil Science and Plant Analyse 23: 687-697.

Harris, G. \& Banasik, O.J. 1952. Effects of environment, variety and season on barley quality. Cereal Chemistry 29: $148-155$.

Hayter, A.M. \& Riggs, T.J. 1973. Environmental and varietal differences in diastatic power for associated characteristics of spring barley. Journal of Agricultural Science, Cambridge 80: 297-230.

Helenius, J. 1992. Ohran $\beta$-amylaasiaktiivisuuteen tilatasolla vaikuttavat tekijăt. University of Helsinki, Department of Plant Production (M.S. thesis). 45 p.

Joy, P. \& Peltonen, J. 1993. Breeding implications of the negative correlation between yield and protein concentration in a winter wheat population. Acta Agriculturae Scandinavica 43: 82-88.

Lawlor, D.W., Boyle, F.A., Kendall, A.C. \& Keys, A.J. 1987. Nitrate nutrition and temperature effects on wheat:
Enzyme composition, nitrate and total amino acid content of leaves. Journal of Experimental Botany 38: 378392.

Mukula, J. \& Rantanen, O. 1989. Climatic risks to the yield and quality of field crops in Finland. VI. Barley 19691986. Annales Agriculturae Fenniae 28: 29-36.

Nelson, L.A. \& Andersen, R.L. 1977. Partitioning of soil test crop response probability. In: T.R. Peck et al. (eds.) Soil Testing: Correlation and Interpreting the Analytical Results. ASA Special Publication 29. ASA, Madison. WI. p. 19-38.

Peltonen, J. 1992. Ear developmental stage used for timing supplemental nitrogen application to spring wheat. Crop Science 32: 1029-1033.

-, Virtanen, A. \& Haggrén, E. 1995. Using a chlorophyll meter to optimize nitrogen fertilizer application for intensively-managed small-grain cereals. Journal of Agronomy and Crop Science 174: 309-318.

Turley, R.H. \& Ching, T.M. 1986. Storage protein accumulation in "Scio" barley seed as affected by late application of nitrogen. Crop Science 26: 778-782.

Waddington, S.R., Cartwright, P.M. \& Wall, P.C. 1983. A quantitative scale of spike initial and pistil development in barley and wheat. Annales of Botany 51: 119-130.

Zadoks, J.C., Chang, T.T. \& Konzak, C.F. 1974. A decimal code for the growth stages of cereals. Weed Research 14: 415-421.

\section{SELOSTUS}

\section{Kymppi-ohran $\beta$-amylaasin tuotannon optimointi lehtivihreämittarin avulla}

\author{
Jari Peltonen, Ari Virtanen, Jaakko Helenius, Juha Salopelto, Kari Kiltilä ja Esko Eloranta \\ Kasvintuotannon tarkastuskeskus, Cultor Oy ja Neson Oy
}

Tutkimuksessa määritettiin Kymppi-ohran lehtivihreäpitoisuuksien raja-arvoja parhaan mahdollisen sadonmuodostuksen ja $\beta$-amylaasi-aktiivisuuden kannalta. Lehtivihreämittaukset tehtiin kasvukaudella 1993 ja 1994 pelto-oloihin tarkoitetulla Minoltan SPAD-502 lehtivihreämittarilla. Mittauksissa käytettiin ylimpiä, täysin kehittyneitä lehtiä. Kenttäkokeina olivat typpitasokokeet $\left(0-200 \mathrm{~kg} \mathrm{~N} \mathrm{ha}^{-1}\right)$. Lehtivihreämittaukset selittivät $\beta$-amylaasi-aktiivisuutta parhaiten tähkälletulovaiheessa (Zadoksin kasvuasteessa 52-58). Taulukossa 4 on yhteenveto Kymppi-ohran lehtivihreän raja-arvoista tässä kasvuasteessa. Lehtivihreän raja-arvo 37 SPAD rajoitti selvästi Kympin sadonmuodostusta. Sadon menetys oli tällöin $1868 \mathrm{~kg} \mathrm{ha}^{-1}$. Jos lehtivihreä- mittaus oli alempi kuin 41 SPAD, laski sadon valkuaispitoisuus 4,7 prosenttiyksikköä ja $\beta$-amylaasi-aktiivisuus 143 W.K. Lehtivihreän raja-arvot optimisadolle olivat 37-41 SPAD-yksikköä, ja parhaalle mahdolliselle valkuaispitoisuudelle ja $\beta$-amylaasi-aktiivisuudelle 41 45 SPAD-yksikköä. Tutkimus osoitti ohran jyvien $\beta$ amylaasin määrän nousevan voimakkaasti vasta sato-optimin jälkeen. Sato-optimin jälkeen jokaista kymmentä $\beta$-amylaasi-aktiivisuuden yksikköä kohden tarvitaan lisä-N noin $11 \mathrm{~kg} \mathrm{ha}^{-1}$. Paras mahdollinen $\beta$-amylaasiaktiivisuus oli keskimäärin 252 W.K. ja vastaava valkuaispitoisuus $14,2 \%$. Sadonkorjuun jälkeen voidaan ohran jyvien valkuaispitoisuuden avulla arvioida epäsuorasti jyvien $\beta$-amylaasi-aktiivisuutta. 